\title{
Discordant Io-ages and the uranium and thorium distribution between zircon and host rocks*
}

\author{
TAKAAKI FuKUOKa AND KUniHIKo KigOSHI \\ Department of Chemistry, Faculty of Science, Gakushuin \\ University, Mejiro, Toshimaku, Tokyo 171, Japan.
}

(Received April 23, 1974)

\begin{abstract}
Io-ages obtained for glass-zircon pairs which were not consistent with expected ages were discussed ont he basis of uranium and thorium distribution between zircon and glass. Uranium and thorium distribution between zircon and host rocks from dacites and granites were also discussed.

Discordant Io-ages obtained for glass-zircon pairs with normal $(\mathrm{Th} / \mathrm{U})_{\text {zircon }}$ ' $(\mathrm{Th} / \mathrm{U})_{\text {glass }}$ ratio are explained by early stage crystallization of the zircon in the magma. Discordant Io-ages with abnormal $(\mathrm{Th} / \mathrm{U})_{\text {zircon }} /(\mathrm{Th} / \mathrm{U})_{\text {glass }}$ ratios suggest that the zircon was captured in the magma as xenocryst. The discrepancy between (Th/ $\mathrm{U})_{\text {zircon }} /(\mathrm{Th} / \mathrm{U})_{\text {glass }}$ ratios (about 0.19$)$ for dacites and $(\mathrm{Th} / \mathrm{U})_{\text {zircon }} /(\mathrm{Th} / \mathrm{U})_{\text {whole }}$ rock ratios (about 0.12 ) for granites could be explained by crystallization of granitic zircon from liquid having chemical composition different from that of the whole rock of granite.
\end{abstract}

\section{INTRODỤCTION}

FUKUOKA and KIgOSHI (1970) and FUKUOKA (1974) reported several Io-ages for volcanic rocks. Most of these ages agreed with other age data, such as ${ }^{14} \mathrm{C}$-ages, fission track ages and/or stratigraphic sequence. The Io-ages for Ata pyroclastic flow in southern Kyushu and Hijiori pyroclastic flow in northern Honshu, Japan, determined for glass-zircon pairs, were two exceptions. The Io-age for Ata was discordant with the ${ }^{14} \mathrm{C}$-ages and the stratigraphic sequence reported by ARAMAKI (1969) and UI (1971). The Io-age of Hijiori obtained for a glass-zircon pair was older than the Ioage obtained for a glass-plagioclase pair and the ${ }^{14} \mathrm{C}$-age. The following two possibilities were given by FuKUOKA and KIGOSHI (1970) to explain these discrepancies: (I) The zircon used for the dating was captured in the magma as xenocryst. (II) The zircon

* This study has been undertaken by T.F. in partial fulfillment for the degree of Doctor of Science at Gakushuin University. 
was crystallized from the magma at an early stage of magmatic crystallization. They suggested that the estimation of rearly occurred process could be made by the study of trace element distribution between zircon and host rocks.

In this paper, discordant Io-ages are disiussed on the basis of uranium and thorium distribution between zircon and glass.

\section{SAMPLES}

The granite samples analyzed in this study were following two.

1) Takakumayama Granite: Biotite granodiorite collected from Kagoshima Prefecture, Kyushu, Japan.

2) Osumi Granite: Hornblende biotite granodiorite collected from Kagoshima Prefecture, Kyushu, Japan.

Geological descriptions for these samples are given in SHibata (1967).

\section{Analytical Results}

Mineral separation and analytical procedure of uranium and thorium are similar to those described in FukUoKa (1974). The analytical results are shown in Table 1. Over-all errors are estimated to be about 8 and $4 \%$ for uranium and thorium analyses, respectively (FUKUOKA, 1974).

Table 1. Uranium and thorium contents of whole rock and zircon from granites in southern Kyushu

\begin{tabular}{|c|c|c|c|}
\hline Locality & Phase & $\mathrm{U}(\mathrm{ppm})$ & Th (ppm) \\
\hline Takakumayama & $\begin{array}{l}\text { whole rock } \\
\text { zircon }\end{array}$ & $\begin{aligned} 7.73 & \pm 0.18 \\
1040 & \pm 40\end{aligned}$ & $\begin{array}{l}20.8 \pm 0.8 \\
334 \pm 19\end{array}$ \\
\hline Osumi & $\begin{array}{l}\text { whole rock } \\
\text { zircon }\end{array}$ & $\begin{array}{ll}3.44 & \pm 0.15 \\
563 & \pm 22\end{array}$ & $\begin{array}{l}10.9 \pm 0.6 \\
212 \pm 11\end{array}$ \\
\hline
\end{tabular}

Errors are standard deviations calculated from counting statistics.

\section{Discussion}

The uranium and thorium inclusion in zircon is generally interpreted by the substitution of $\mathrm{U}^{4+}(r=0.97 \mathrm{~A})$ and $\mathrm{Th}^{4+}(r=1.02 \mathrm{~A})$ ions for $\mathrm{Zr}^{4+}(r=0.79 \mathrm{~A})$ (e.g. GOLDSCHMIDT, 1954).

When the exchange equilibria

and

$$
(\mathrm{Zr})_{\mathrm{s}}+(\mathrm{Th})_{\ell} \stackrel{K_{\mathrm{Th}}}{\rightleftharpoons}(\mathrm{Th})_{\mathrm{s}}+(\mathrm{Zr})_{\ell}
$$

$$
(\mathrm{Zr})_{\mathrm{S}}+(\mathrm{U})_{\ell} \stackrel{K_{\mathrm{U}}}{=}(\mathrm{U})_{\mathrm{s}}+(\mathrm{Zr})_{\ell}
$$


hold at the growth of zircon crystals, the equilibrium constants $K_{\mathrm{Th}}$ and $K_{\mathrm{U}}$ are given as follows:

$$
K_{\mathrm{Th}}=\frac{(\mathrm{Th} / \mathrm{Zr})_{\mathrm{S}}}{(\mathrm{Th} / \mathrm{Zr})_{\ell}}
$$

$$
K_{\mathrm{U}}=\frac{(\mathrm{U} / \mathrm{Zr})_{\mathrm{S}}}{(\mathrm{U} / \mathrm{Zr})_{\ell}}
$$

where $s$ and $\ell$ denote solid and liquid phases, respectively. The partition coefficient of a specified element between two phases is given by the ratio of the concentrations in both phases. For instance, the partition coefficient of uranium $D_{\mathrm{U}}$ is given by $D_{\mathrm{U}}=$ $(\mathrm{U})_{S} /(U)_{\ell}$. Because we have no direct information on the concentration of the specified element in liquid phase in equilibrium with solid phase, this value is supposed to be nearly equal to the concentration in glass (in the case of dacite) or in whole rock (in the case of granite). The partition coefficients of zirconium, uranium and thorium $\left(D_{\mathrm{Zr}}, D_{\mathrm{U}}\right.$, and $\left.D_{\mathrm{Th}}\right)$ between zircon and glass or whole rock show the relation of $D_{\mathrm{Zr}}$ (ca. 2,000 5,500)* $>D_{\mathrm{U}}(c a .100 \sim 200)>D_{\mathrm{Th}}(c a .15 \sim 30)$ (see Table 2). This order is in accord with the ionic radii of $\mathrm{Zr}^{4+}, \mathrm{U}^{4+}$ and $\mathrm{Th}^{4+}$ ions. Dividing (2) by $\left(2^{\prime}\right)$, we obtain:

$$
\frac{K_{\mathrm{Th}}}{K_{\mathrm{U}}}=\frac{(\mathrm{Th} / \mathrm{U})_{\mathrm{S}}}{(\mathrm{Th} / \mathrm{U})_{\ell}}=\frac{D_{\mathrm{Th}}}{D_{\mathrm{U}}}
$$

\begin{tabular}{|c|c|c|c|c|c|}
\hline & \multirow{2}{*}{ Locality } & \multicolumn{3}{|c|}{ Partition coefficient } & \multirow{2}{*}{$\frac{(\mathrm{Th} / \mathrm{U})_{\text {zircon }}}{(\mathrm{Th} / \mathrm{U})_{\text {glass }}}$} \\
\hline & & & $D_{\mathrm{U}}$ & $D_{\mathrm{Th}}$ & \\
\hline \multirow{10}{*}{ Dacite } & Kakuto $^{* 2)}$ & & & & $0.194 \pm 0.015$ \\
\hline & Ito*2) & 140 & \pm 9 & $30.3 \pm 2.1$ & $0.217 \pm 0.021$ \\
\hline & Ata $* 2)$ & 369 & \pm 17 & $229 \pm 14$ & $0.620 \pm 0.047$ \\
\hline & Ikeda*2) & 90.0 & \pm 2.9 & $17.7 \pm 1.3$ & $0.196 \pm 0.015$ \\
\hline & Torihama*2) & 129 & \pm 4 & $24.8 \pm 1.4$ & $0.193 \pm 0.012$ \\
\hline & Hijiori $^{* 3)}$ & & & & $0.180 \pm 0.004$ \\
\hline & Pm-I (Ontake)-(1) *3),*4) & & & & $0.198 \pm 0.029$ \\
\hline & Pm-I (Ontake)- (2) $* 3), * 4)$ & & & & $0.246 \pm 0.007$ \\
\hline & Pm-I (Ontake)-(3) *3), *4) & & & & $0.0974 \pm 0.0036$ \\
\hline & Summer Lake*3) & & & & $0.172 \pm 0.007$ \\
\hline \multirow{2}{*}{ Granite } & Takakumayama & 135 & \pm 6 & $16.1 \pm$ & $0.119 \pm 0.009^{* 1)}$ \\
\hline & Osumi & 164 & \pm 10 & $19.4 \pm 1.4$ & $0.119 \pm 0.011^{* 1)}$ \\
\hline
\end{tabular}

Table 2. Partition coefficients of uranium and thorium between zircon and glass or whole rock, and $(\mathrm{Th} / \mathrm{U})_{\text {zircon }} /(\mathrm{Th} / \mathrm{U})_{\text {glass }}$ or whole rock ratios

All errors are calculated only from counting statistics.

*1) $(\mathrm{Th} / \mathrm{U})_{\text {zircon }} /(\mathrm{Th} / \mathrm{U})_{\text {whole rock }}$

*2) Calculated from the values given by FUKUOKA (1974).

*3) Calculated from the values given by FUKUOKA and KIGOSHI (1970).

*4) See Fig.1.

* FUKUOKA and SEKI (1973). Calculated from zirconium content of glass coexisting with zircon. 
Since the dependences of $K_{\mathrm{Th}}$ and $K_{\mathrm{U}}$ on temperature, pressure and also on the major element composition of the system might be similar, the ratio given by Eq. (3) would not depend so strongly on these factors as $K_{\mathrm{Th}}$ and $K_{\mathrm{U}}$.

The $(\mathrm{Th} / \mathrm{U})_{\text {zircon}} /(\mathrm{Th} / \mathrm{U})_{\text {glass }}$ ratios (about 0.19 ) of dacites show good agreement with each other, except those of Ata dacite and zircons (2) and (3) in Pm-I from Ontake volcano (Table 2). The $(\mathrm{Th} / \mathrm{U})_{\text {zircon }} /(\mathrm{Th} / \mathrm{U})_{\text {whole rock }}$ ratios (about 0.12 ) of granites are lower than the $(\mathrm{Th} / \mathrm{U})_{\text {zircon }} /(\mathrm{Th} / \mathrm{U})_{\text {glass }}$ ratios of dacites (Table 2). This may be explained either by crystallization of zircon from thorium-poor magma after crystallization of thorium-rich minerals (such as thorite and monazite) or by removal of uranium-rich fractions from the liquid phase after crystallization of zircon. The latter explanation is consistent with the explanation by NAGASAWA (1970). He suggested that the zircon in Takakumayama granite crystallized from a liquid phase more enriched in heavy rare earth elements than the whole rock granite.

The Io-age of Ata pyroclastic flow obtained directly for glass-zircon pair was much older than the ${ }^{14} \mathrm{C}$-ages (FuKuokA, 1974). This Io-age is also older than the Ioages for Kakuto and Torihama pyroclastic flows which underlie Ata pyroclastic flow. The plotted points of ${ }^{230} \mathrm{Th}$ and ${ }^{238} \mathrm{U}$ of the zircon from Ata pyroclastic flow pumice lie on the isochron of $t=\infty$ (Fig. 1). In the case of Ata pyroclastic dacite, the partition coefficients of uranium and thorium are abnormally high and also the $(\mathrm{Th} / \mathrm{U})_{\text {zircon }} /$ $(\mathrm{Th} / \mathrm{U})_{\text {glass }}$ ratio is high compared with those in other dacites (Table 2). This makes it difficult to connect the zircon in this dacite with zircons in other dacites in the genetic history. Since zircon has high melting point $\left(2,550^{\circ} \mathrm{C}\right.$; POLdERVAarT, 1956), the zircon in this dacite would have been brought as xenocryst from wall rocks which

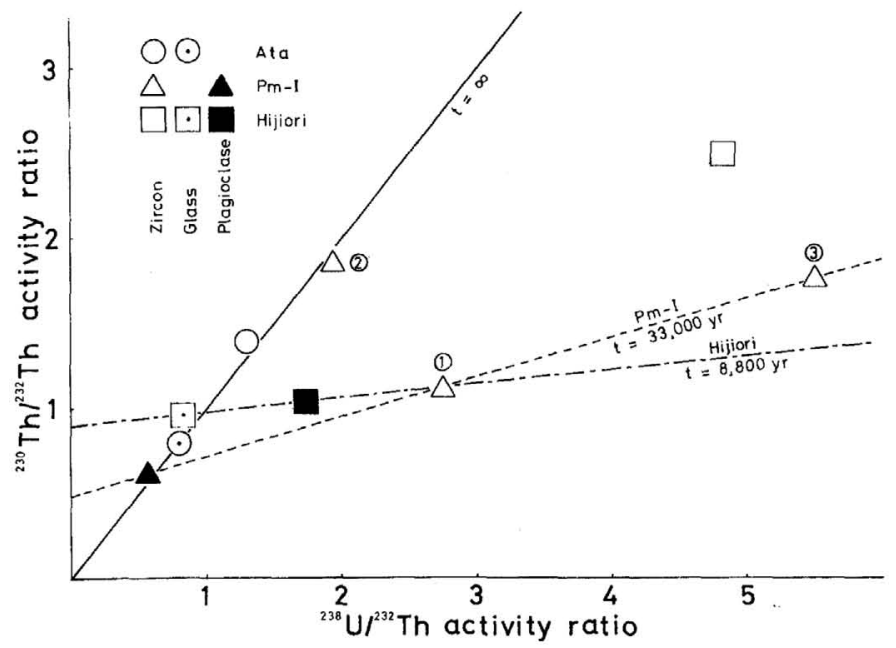

Fig.1. ${ }^{230} \mathrm{Th} /{ }^{232} \mathrm{Th} v .{ }^{238} \mathrm{U} /{ }^{232} \mathrm{Th}$ plot and isochrons Numbers indicated for zircons of Pm-I correspond to the numbers in Table 2. 
might have no genetic relation with the dacite. The $(\mathrm{Th} / \mathrm{U})_{\mathrm{zircon}} /(\mathrm{Th} / \mathrm{U})_{\text {glass }}$ ratio for zircon (2) of Pm-I from Ontake volcano is higher than those for zircons from many other dacites (Table 2). The plot of this zircon does not lie on the isochron (Fig. 1). This zircon seems to have been also captured in the Pm-I magma as xenocryst. For the dacitic zircon, the value of the $(\mathrm{Th} / \mathrm{U})_{\text {zircon }} /(\mathrm{Th} / \mathrm{U})_{\text {glass }}$ ratio seems to be reliable as a measure to estimate the genetic relation between zircon and dacite.

Though the zircon in Hijiori pyroclastic dacite pumice shows a normal $(\mathrm{Th} / \mathrm{U})_{\mathrm{zir}}$ $\operatorname{con} /(\mathrm{Th} / \mathrm{U})_{\text {glass }}$ ratio of about 0.19 (Table 2), the plot of the zircon does not lie on the isochron of Hijiori pyroclastic flow (Fig.1). The glass and this zircon pair presents an Io-age of about 50,000 60,000y. The time gap between this age and the Io-age obtained for glass-plagioclase pair $(8,800 y$; FuKUOKA and KIGoshI, 1970) may show the difference between the time of crystallization of the zircon in the Hijiori dacite magma and the time of eruption of Hijiori pyroclastic flow. Because it is considered that the zircons crystallized from magma at an early stage of crystallization of igneous rocks (LARSEN and PoldervaART, 1957).

\section{CONCLUSION}

(1) The glass-zircon pair of Ata pyroclastic dacite and the glass-zircon (2) pair of Pm-I from Ontake volcano gave discordant Io-ages and showed abnormal $(\mathrm{Th} / \mathrm{U})_{\mathrm{zir}}$ con $/(\mathrm{Th} / \mathrm{U})_{\text {glass }}$ ratios. This seems to suggest that these zircons were captured in the magma as xenocrysts. (2) The glass-zircon pair of Hijiori pyroclastic flow gave a discordant Io-age and showed a normal $(\mathrm{Th} / \mathrm{U})_{\text {zircon }} /(\mathrm{Th} / \mathrm{U})_{\text {glass }}$ ratio (about 0.19 ). This seems to suggest the early stage crystallization of the zircon in the magma.

\section{ACKNOWLEDGMENTS}

The authors are much grateful to Prof. H. NAGASAWA of Gakushuin University for his useful suggestions; to Prof. S. ARAMAKI of the Earthquake Research Institute, University of Tokyo and Dr. T. UI of Yamagata University for sample collections and their useful geological suggestions; to Dr. A. TEZUKA and Mr. M. MORIOKA of Gakushuin University for aid in neutron activation analysis. This work was supported in part by grants from Matsunaga Science Foundation.

\section{REFERENCES}

ARAMAKI, S. (1969) Geology and pyroclastic flow deposits of the Kokubu area, Kagoshima Prefecture. J. Geol. Soc. Japan 75, 425-442 (in Japanese).

FUKUOKA, T. (1974) Ionium dating of acidic volcanic rocks. Geochem. J. 8, 109-116.

FUKUOKA, T. and KIGOSHI, K. (1970) Ionium dating for volcanic ejecta. Bull. Volcan. Soc. Japan, 2nd ser. 15, 111-119 (in Japanese).

FUKUOKA, T. and SEKI, K. (1973) Zirconium contents in acid volcanic rocks. ibid. 18, 118 (abstract, in Japanese).

GoldschmidT, V. M. (1954) Geochemistry, p. 563, Clarendon Press, Oxford. 
LARSEN, L. H. and PoldervaART, A. (1957) Measurement and distribution of zircons in some granitic rocks of magmatic origin. Min. Mag. 31, 544-564.

NAGASAWA, H. (1970) Rare earth concentrations in zircons and apatites and their host dacites and granites. Earth Planet. Sci. Lett. 9, 359-364.

PoldervaART, A. (1956) Zircon in rocks. 2. igneous rocks. Am. J. Sci. 254, 521-554.

SHIBATA, H. (1967) Nihon ganseki-shi Vol. 2, p.350, Asakura Shoten, Tokyo (in Japanese).

UI, T. (1971) Genesis of magma and structure of magma chamber of several pyroclastic flows in Japan. J. Fac. Sci. Tokyo Univ. Sec. II 18, 53-127. 